\title{
Influence of color centers on the luminescent response of radiation-damaged CsI:TI crystal
}

\author{
V.Yakovlev $^{1}$, L.Trefilova $^{2}$, V.Alekseev $^{3}$, A.Karnaukhova $^{1}$, \\ O.Shpylynska ${ }^{3}$, A.Lebedynskiy ${ }^{3}$, O.Tarakhno ${ }^{2}$ \\ ${ }^{1}$ Tomsk Polytechnic University, 30 Lenin Ave., \\ 634034 Tomsk, Russian Federation \\ ${ }^{2}$ National University of Civil Protection of Ukraine, \\ 94 Chernyshevska Str., 61023 Kharkiv, Ukraine \\ ${ }^{3}$ Institute for Scintillation Materials, STC "Institute for Single Crystals", \\ National Academy of Sciences of Ukraine, 60 Nauky Ave., 61001 Kharkiv, Ukraine
}

Received May 29, 2017

Luminescence properties of $\mathrm{TI}^{0} \mathrm{v}_{\mathrm{a}}{ }^{+}$and $\mathrm{Tl}^{2+} \mathrm{v}_{\mathrm{c}}{ }^{-}$color centers induced by irradiation in Csl:TI crystal are studied within a temperature range of 80-300 $\mathrm{K}$. It is found, that electron $\mathrm{TlO}^{0} \mathrm{v}_{a}{ }^{+}$and hole $\mathrm{Tl}^{2+} \mathrm{v}_{\mathrm{c}}^{-}$color centers arising due to radiation damage do not reduce conversion efficiency of Csl:TI crystal, but participate in scintillation process to get energy from $\mathrm{TI}^{+}$centers by resonance. Degradation of the light yield of the irradiated Csl:TI crystal is caused by the radiative energy transfer from $\mathrm{Tl}^{+}$to $\mathrm{Tl}^{0} \mathrm{v}_{\mathrm{a}}^{+}$centers, whose emission is quenched at temperature above $210 \mathrm{~K}$. Non-radiative energy transfer from $\mathrm{Tl}^{+}$ to $\mathrm{Tl}^{2+} \mathrm{v}_{\mathrm{c}}^{-}$centers results in long-wave spectral shift and the duration increase of the scintillation pulse.

Keywords: thallium doped cesium iodide, radiation damage, color center, luminescence, energy transfer.

В температурном интервале 80-300 K исследованы люминесцентные свойства $\mathrm{Tl}^{0} \mathrm{v}_{\mathrm{a}}^{+}{ }^{+}$и $\mathrm{Tl}^{2+} \mathrm{v}^{-}$центров, образующихся при облучении кристалла Csl:TI. Установлено, что электронные $\mathrm{TI}^{0} \mathrm{v}_{\mathrm{a}}^{+}$и дырочные $\mathrm{Tl}^{2+} \mathrm{v}_{\mathrm{c}}^{-}$центры окраски, возникающие из-за радиационного повреждения, не уменьшают конверсионную әффективность кристалла Csl:TI, но участвуют в сцинтилляционном процессе, получая энергию от $\mathrm{Tl}^{+}$центров. Деградация светового выхода облученного кристалла CSl:TI обусловлена излучательным переносом энергии от $\mathrm{Tl}^{+} \mathrm{\kappa}$ $\mathrm{Tl}^{0} \mathrm{v}_{\mathrm{a}}^{+}$центрам, свечение которых потушено при температуре выше $210 \mathrm{~K}$. Безызлучательный перенос энергии от $\mathrm{Tl}^{+} \mathrm{\kappa} \mathrm{Tl}^{2+} \mathrm{v}_{\mathrm{c}}^{-}$центрам приводит к длинноволновому сдвигу спектра и увеличению длительности сцинтилляционного импульса кристалла Csl:TI.

Вплив центрів забарвлення на люмінесцентний відгук пошкодженого радіацією кристала Csl:TI. В.Яковлєв, Л.Трефілова, В.Алексєєв, Г.Карнаухова, О.ШШпилинська, О.Лебединський, О.Тарахно.

у температурному інтервалі 80-300 K досліджено люмінесцентні властивості $\mathrm{TI}^{0} \mathrm{v}_{a}{ }^{+}$ и $\mathrm{Tl}^{2+} \mathrm{v}_{\mathrm{c}}^{-}$центрів забарвлення, що утворюються при опроміненні кристала Csl:TI. Bcтановлено, що електронні $\mathrm{Tl}^{0} \mathrm{v}_{\mathrm{a}}^{+} \mathrm{i}$ діркові $\mathrm{Tl}^{2+} \mathrm{v}_{\mathrm{c}}^{-}$центри, які виникають внаслідок радіаційного пошкодження, не зменшують конверсійну ефективність кристала Csl:TI, але беруть участь у сцинтиляційному процесі, отримуючи резонансним шляхом енергію від $\mathrm{TI}^{+}$центрів. Деградація світлового виходу опроміненого кристала Csl:TI обумовлена випромінювальним переносом енергії від $\mathrm{TI}^{+}$до $\mathrm{TI}^{0} \mathrm{v}_{a}^{+}$центрів, випромінювання яких погашено при температурах, що перевищують $210 \mathrm{~K}$. Безвипромінювальний перенос енергії від $\mathrm{Tl}^{+}$до $\mathrm{Tl}^{2+} \mathrm{v}_{\mathrm{c}}^{-}$центрів забарвлення призводить до довгохвильового зсуву спектра і збільшення тривалості сцинтиляційного імпульсу кристала Csl:TI. 


\section{Introduction}

Irradiation of CsI:Tl crystals gives rise $\mathrm{T}^{0} \mathrm{~V}_{\mathrm{a}}{ }^{+}$and $\mathrm{T}^{2+} \mathrm{V}_{\mathrm{c}}{ }^{-}$activator color centers where the electron $\mathrm{Tl}^{0}$ and hole $\mathrm{T}^{2+}$ center are perturbed by a neighbor anionic $\mathrm{V}_{a}^{+}$and a cationic $\mathrm{v}_{\mathrm{c}}^{-}$vacancy, respectively [1]. The Coulomb field of the vacancies increases thermal stability of $\mathrm{Tl}^{0}$ and $\mathrm{Tl}^{2+}$ color centers, thereby changing the mechanism of their participation in the scintillation process. The activator color centers induced by high-dose irradiation negatively influence on the scintillation characteristics of CsI:T| crystal due to overlapping of their absorption bands with the spectrum of $\mathrm{Tl}^{+}$centers (Fig. 1). In the literature there are discussed two factors leading to degradation of the light yield of irradiated CsI:TI crystals: reabsorption [2-5] and decrease of conversion efficiency [6,7]. The former factor is confirmed, in particular, by a linear rise of the light yield losses with increasing thickness of CsI:Tl samples irradiated with the same dose, thereat the light yield of the samples with a thickness less than 5-10 mm remains unchanged [2]. However, certain experimental results can not be explained only by re-absorption. In particular, the light yield losses in CsI:TI samples subjected to irradiation diminish as the activator content increases (see Fig. 5 in [7]). Moreover, high-dose irradiation causes changes in the spectrum [8] and the scintillation pulse shape of Csl:TI [9]. Therefore, the light yield degradation is explained by the scintillation efficiency decrease due to formation of vacancy clusters which act as quenching centers and effectively compete with $\mathrm{Tl}^{+}$centers in capture of electron excitations $[6,7]$. However, such model of quenching centers is inconsistent with the fact that exposure not only to $\gamma$-radiation but also to daylight of CsI:Tl crystals contaminated by borate, carbonate and hydroxide ions gives rise the same $\mathrm{Tl}^{0} \mathrm{~V}_{a}{ }^{+}$and $\mathrm{Tl}^{2+} \mathrm{V}_{\mathrm{c}}{ }^{-}$activator color centers [10], though the energy of light photons is insufficient for creation of vacancies. According to [9], ionizing radiation generates lattice defects in Csl:TI crystals, which are shallow hole capture centers. The phonon-assisted release of $V_{k}$ centers from these traps retards $\left.T\right|^{0}-V_{k}$ recombination to increase the decay duration of $\mathrm{Tl}^{+}$scintillations. Note, up to now there do not exist any experimental evidences that irradiation stimulates formation of the shallow traps for $V_{k}$ centers as well as vacancy clusters in Csl:Tl crystal. Therefore, it is still

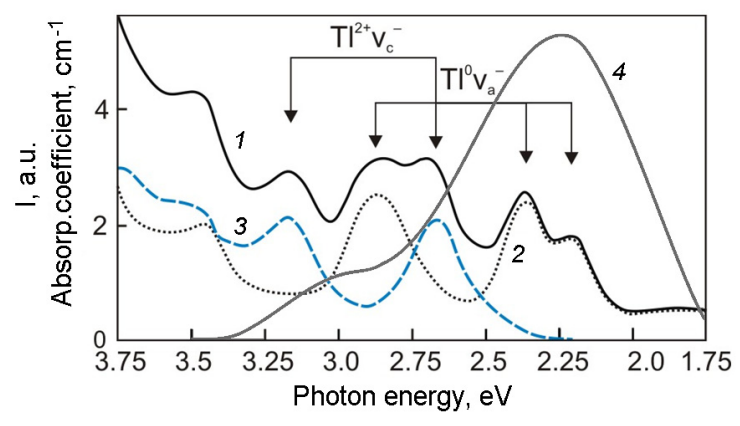

Fig. 1. Absorption spectra of $\gamma$-irradiated Csl:TI measured at $295 \mathrm{~K}$ before (1) and after annealing (2) at $373 \mathrm{~K}$ [11]. Difference spectrum (3) obtained by the subtraction of the spectrum (2) from spectrum (1). Radioluminescence spectrum of non-irradiated Csl:TI at $295 \mathrm{~K}(4)$.

unclear what processes cause change of the scintillation pulse shape and whether irradiation reduces the conversion efficiency of CsI:Tl.

In the present work we have used another approach to interpretation of scintillation process in irradiated Csl:TI crystal which is based on two experimentally proved facts. Firstly, excitation of the main $\mathrm{Tl}^{+}$centers results in non-radiative energy transfer to $\mathrm{Tl}^{2+} \mathrm{V}_{\mathrm{C}}{ }^{-}$color centers [1]. Secondly, with the increase of the activator concentration the ratio between the numbers of $\mathrm{T}^{0} \mathrm{~V}_{\mathrm{a}}{ }^{+}$and $\mathrm{Tl}^{2+} \mathrm{V}_{\mathrm{c}}{ }^{-}$centers formed under the same irradiation dose rises in favor of $\left.T\right|^{2+} \mathrm{V}_{\mathrm{C}}-$ centers [11]. The paper deals with the spectral-kinetic properties of radiation-induced $\mathrm{T}^{0} \mathrm{~V}_{\mathrm{a}}{ }^{+}$and $\mathrm{T}^{2+} \mathrm{V}_{\mathrm{c}}{ }^{-}$color centers. The presented results prove that degradation of the light yield of irradiated CsI:Tl crystals is caused only by re-absorption of $\mathrm{T}^{\mathrm{O}} \mathrm{V}_{\mathrm{a}}{ }^{+}$centers, whereas $\mathrm{T}^{2+} \mathrm{V}_{\mathrm{c}}{ }^{-}$centers are responsible for the long-wavelength shift of the scintillation spectrum and change of the scintillation pulse shape.

\section{Experimental}

The study was carried out for CsI:TI samples containing the carbonate ions $\mathrm{CO}_{3}{ }^{2-}$, which stimulate formation of $\mathrm{TIOV}_{a}{ }^{+}$and $\mathrm{T}^{2+} \mathrm{V}_{\mathrm{C}}{ }^{-}$centers under irradiation. Csl: $\mathrm{Tl}$ crystal was grown by seeding in an argon atmosphere. The concentration of $\mathrm{CO}_{3}{ }^{2-}$ ions determined optically by the absorption coefficient in the maximum of their deformation band peaking at $878 \mathrm{~cm}^{-1}[11]$ amounted to $4.7 \cdot 10^{-4}$ mole $\%$. The concentration of $\mathrm{Tl}$ determined by the chemical method [12] amounted to $8 \cdot 1 \cdot 10^{-2}$ mole $\%$. CsI:TI samples were colored at room tem- 
perature by $\gamma$-rays from ${ }^{60} \mathrm{Co}$ source $(D=$ $1 \cdot 10^{6}$ Gy). The absorption spectra were measured by a SF-26 spectrophotometer. Luminescence excited in the steady-state regime by emission of a DDS-400 deuterium lamp through a MDR-2 monochromator as well as by $\gamma$-rays from ${ }^{241} \mathrm{Am}$ source was analyzed by a MDR-23 monochromator and registered by a FEU-100 photomultiplier. Time-resolved luminescence was excited by laser pulses $\left(\mathrm{YAlO}_{3}-\mathrm{Nd}^{3+}\right.$, the second harmonic $\lambda=540 \mathrm{~nm}(2.29 \mathrm{eV}), t_{1 / 2}=30 \mathrm{~ns}$, $J=100 \mathrm{~mJ} / \mathrm{cm}^{2}$ ) and by pulses of accelerated electrons $\left(E_{e}=0.25 \mathrm{MeV}, J=\right.$ $8 \mathrm{~A} / \mathrm{cm}^{2}, t_{1 / 2}=15 \mathrm{~ns}$ ) and registered by an optical spectrometer consisting of an MDR3 monochromator, an FEU-106 photomultiplier and a GDS-2204 digital oscilloscope with a time resolution of $7 \mathrm{~ns}$. All necessary corrections of the spectra have been made. The measurements were carried out within a temperature range of $80-300 \mathrm{~K}$.

\section{Results and discussion}

The ratio between the numbers of the electronic $\mathrm{TlO}^{0} \mathrm{~V}_{\mathrm{a}}^{+}$and hole $\mathrm{Tl}^{2+} \mathrm{V}_{\mathrm{c}}{ }^{-}$centers in a radiation-colored Csl:TI crystal can be changed by illumination in $2.9 \mathrm{eV}$ band of $\mathrm{T} \mid \mathrm{V}_{\mathrm{a}}{ }^{+}$centers or annealing. Fig. 1 shows the absorption spectra of the radiation-colored Csl:Tl, where the absorption bands for $\mathrm{T}^{0} \mathrm{~V}_{\mathrm{a}}{ }^{+}$ and $\mathrm{Tl}^{2+} \mathrm{V}_{\mathrm{c}}{ }^{-}$color centers are denoted by arrows. $\mathrm{T}^{2+} \mathrm{V}_{\mathrm{c}}{ }^{-}$centers have lower thermal stability in comparison with $\mathrm{TlO} \mathrm{V}^{+}$centers. The annealing of the crystal at temperatures not exceeding $390 \mathrm{~K}$ destroys $\mathrm{T}^{2+} \mathrm{V}_{\mathrm{c}}{ }^{-}$ centers, but practically does not affect the $\mathrm{TlO}_{\mathrm{a}}{ }^{+}$centers. The observed "survival" of the electronic activator centers in the process of the thermal destruction of hole activator centers under the low temperature annealing can be explain by thermal ionization of $\mathrm{Tl}^{2+} \mathrm{V}_{\mathrm{C}}{ }^{-}$centers with formation the more stable intrinsic hole centers responsible for the band peaking at $3.44 \mathrm{eV}$.

Illumination of $\gamma$-irradiated Csl:Tl crystal with $436 \mathrm{~nm}$ filtered light of mercury arc causes optical ionization of $\mathrm{T}^{0} \mathrm{OV}_{\mathrm{a}}{ }^{+}$centers with formation of $\mathrm{Tl}^{2+} \mathrm{V}_{\mathrm{c}}{ }^{-}$centers (Fig. 2) due to the electron recombination with $\mathrm{I}_{3}{ }^{-}$ centers [1]. The study of the luminescent properties of Csl:Tl sample containing virtually one of two $\mathrm{Tl}^{2+} \mathrm{V}_{\mathrm{c}}{ }^{-}$and $\mathrm{T}^{0} \mathrm{~V}_{\mathrm{a}}{ }^{+}$color centers makes possible to clarify how each participates in the scintillation process. Table 1 shows the maxima of absorption bands specific to these centers.

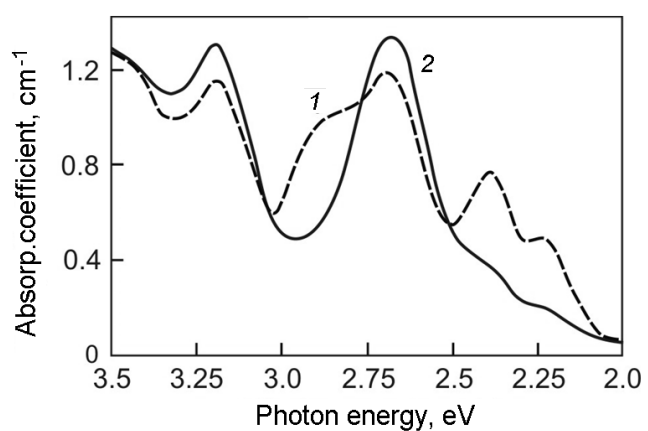

Fig. 2. Absorption spectra of $\gamma$-irradiated Csl:TI crystal measured at $295 \mathrm{~K}$ before (1) and after illumination with $436 \mathrm{~nm}$-filtered light of mercury arc (2).

Table 1. Absorption band maxima related to $\mathrm{Tl}^{0} \mathrm{v}_{\mathrm{a}}{ }^{+}$and $\mathrm{Tl}^{2+} \mathrm{v}_{\mathrm{c}}{ }^{-}$centers at $295 \mathrm{~K}$ and $80 \mathrm{~K}$ (in brackets)

\begin{tabular}{|c|ccc||}
\hline \hline Color center & \multicolumn{3}{|c|}{ Position of maximum, eV } \\
\hline $\mathrm{TI}^{2+} \mathrm{v}_{\mathrm{c}}^{-}$ & 3.18 & 2.67 & \\
& $(3.14)$ & $(2.58)$ & \\
\hline $\mathrm{TI}^{0} \mathrm{v}_{\mathrm{a}}^{+}$ & 2.88 & 2.38 & 2.21 \\
& $(2.82)$ & $(2.32)$ & $(2.23)$ \\
\hline
\end{tabular}

\subsection{Luminescence properties of $T^{0} \mathrm{~V}_{\mathrm{a}}^{+}$} center

$\mathrm{T}^{0} \mathrm{~V}_{\mathrm{a}}{ }^{+}$center luminescence was studied for Csl:Tl crystal annealed at $373 \mathrm{~K}$, whose absorption spectrum is shown in Fig. 1 (curve 2). Luminescence is excited in nonelementary band peaking at $2.25 \mathrm{eV}$, which overlaps two $\mathrm{T}^{0} \mathrm{~V}_{\mathrm{a}}{ }^{+}$center absorption bands with maxima at 2.32 and $2.38 \mathrm{eV}$ at $80 \mathrm{~K}$. The luminescence spectrum of $\mathrm{Tl}^{\mathrm{O}} \mathrm{V}_{\mathrm{a}}{ }^{+}$centers fits a Gaussian with parameters $E_{m}=$ $1.96 \mathrm{eV}$ and FWHM $=0.18 \mathrm{eV}$ (Fig 3a).

With temperature rise the luminescence intensity diminishes according to Mott's quenching law:

$$
I_{1}(T)=I_{0} \cdot \eta_{L}(T)=\frac{I_{0}}{1+\frac{p_{0}^{1}}{P_{L}} e^{-\frac{E_{1}}{k T}}},
$$

where $I_{0}-$ the photoluminescence intensity at $T \rightarrow 0 ; \eta_{L}-$ quantum luminescence yield; $P_{L}-$ the probability of luminescence; $E_{1}$ and $p_{0}{ }^{1}$ - the activation energy and frequency factor, respectively, for the quenching process of intra-center luminescence. Table 2 lists the best fit parameter values for temperature dependence of $\mathrm{T}^{0} \mathrm{~V}_{\mathrm{a}}{ }^{+}$center 

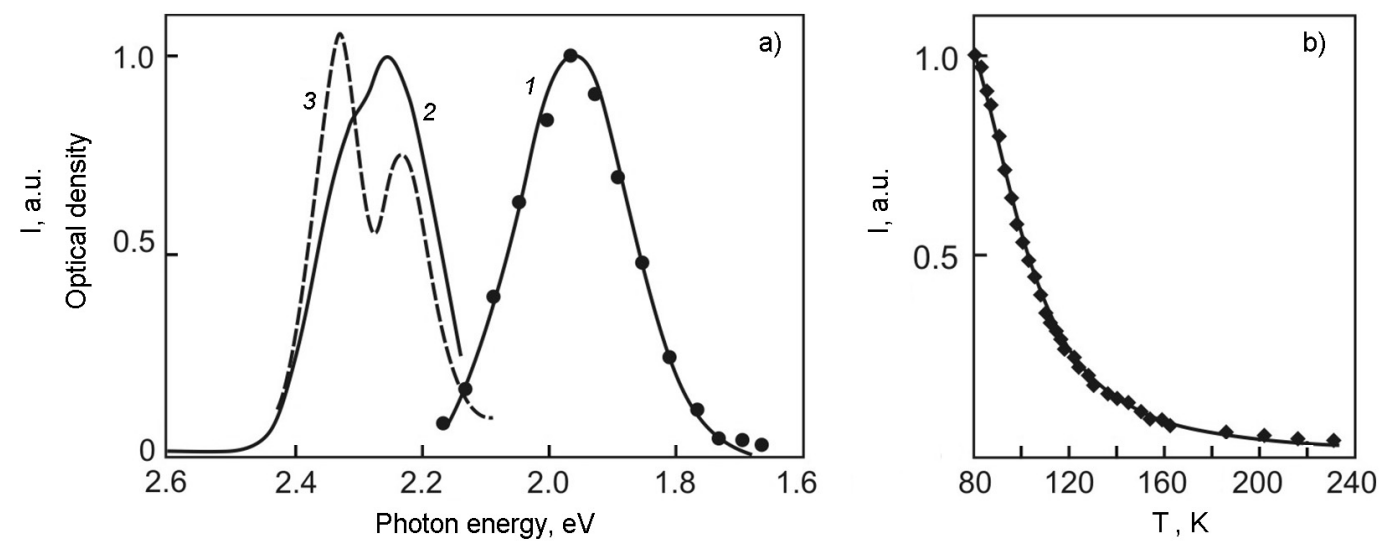

Fig. 3. a) Fragment of the induced absorption spectrum of radiation-damaged Csl:Tl crystal (curve 1 after [13]). Excitation spectrum for $\lambda_{\text {lum }}=1.96 \mathrm{eV}$ (curve 2) and luminescence spectrum at $\lambda_{\text {ex }}=$ $2.34 \mathrm{eV}$ (curve 3, where full circles - experimental values (after [13]); the solid line - the fitting Gaussian) which are measured after annealing for $7 \mathrm{~h}$ at $T=373 \mathrm{~K}$. All spectra are registered at $T$ $=80 \mathrm{~K}$. b) Temperature dependence of $1.96 \mathrm{eV}$ luminescence intensity, where full rhombs experimental values; the solid line - the fitting curve.

luminescence intensity calculated by the equation (1). As one can see in Fig. 3b, $\mathrm{T} \mid \mathrm{V}_{\mathrm{a}}{ }^{+}$center luminescence is practically quenched at temperatures above $210 \mathrm{~K}$, at which Csl:Tl crystal is used as scintillation material.

3.2. Luminescence properties of $\mathrm{Tl}^{2+} \mathrm{V}_{\mathrm{c}}^{-}$ center

The luminescence spectra excited at $80 \mathrm{~K}$ in $\mathrm{T}^{2+} \mathrm{V}_{\mathrm{C}}-$ center absorption bands with maxima $3.14 \mathrm{eV}$ and $2.58 \mathrm{eV}$ are different from each other (Fig. 4). The luminescence spectrum excited in $3.14 \mathrm{eV}$ absorption band of $\mathrm{Tl}^{2+} \mathrm{V}_{\mathrm{C}}{ }^{-}$center is a superposition of two bands, which is fitted by two Gaussians with maxima at $2.08 \mathrm{eV}$ and $1.82 \mathrm{eV}$. Only the short-wave band peaking at $2.08 \mathrm{eV}$ is excited in $2.58 \mathrm{eV}$ absorption band of $\mathrm{T}^{2+} \mathrm{V}_{\mathrm{C}}{ }^{-}$center, whereas the long-wave band peaking at $1.82 \mathrm{eV}$ appears together with $1.96 \mathrm{eV}$ band at excitation in $2.32 \mathrm{eV}$ absorption band of $\mathrm{T}^{0} \mathrm{~V}_{\mathrm{a}}{ }^{+}$center. As one can see in Fig. 5 (curve 1), the luminescence spectrum of Csl:Tl crystal containing $\mathrm{Tl}^{0} \mathrm{~V}_{a}{ }^{+}$ and $\mathrm{Tl}^{2+} \mathrm{V}_{\mathrm{c}}{ }^{-}$centers in comparable quantities is a sum of their bands with maxima at $1.96 \mathrm{eV}$ and $1.82 \mathrm{eV}$, respectively. Unlike the spectrum luminescence measured at steady-state excitation, the band with maximum $1.82 \mathrm{eV}$ explicitly manifests in the spectrum of the same crystal measured with $1 \mu \mathrm{s}$ delay after the exciting pulse depletion (Fig. 5, curve 2). The band peaking at $1.82 \mathrm{eV}$ can be also observed at steady-state excitation of Csl:Tl crystal (Fig. 5, curve 3),

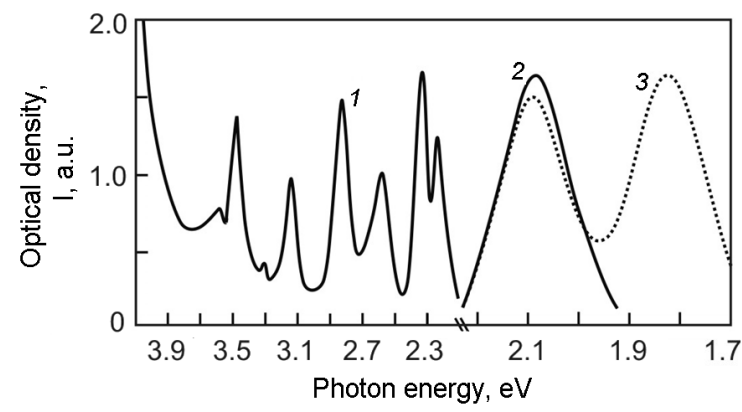

Fig. 4. a) Absorption (1) and luminescence $(2,3)$ spectra of $\gamma$-irradiated CsI(TI) crystal at $80 \mathrm{~K}$ after [13]: $E_{e x}=3.14 \mathrm{eV}$ (2) and $E_{e x}=$ $2.58 \mathrm{eV}(3)$.

Table 2. Best fitting set of parameters for temperature behavior of $\mathrm{TI}^{0} \mathrm{v}_{\mathrm{a}}{ }^{+}$center luminescence

\begin{tabular}{|c|c|c||}
\hline \hline$I_{0}$ & $\frac{p_{1}^{0}}{P_{L}}$ & $E_{1}(\mathrm{eV})$ \\
\hline 1.35 & 660 & 0.053 \\
\hline
\end{tabular}

where number of $\mathrm{T}^{2+} \mathrm{V}_{\mathrm{C}}{ }^{-}$centers is dominant (Fig. 2). The luminescence band peaking at $1.82 \mathrm{eV}$ decays exponentially with a time constant $1 \mu \mathrm{s}$ and $0.76 \mu \mathrm{s}$ at 80 and $295 \mathrm{~K}$, respectively (Fig. 6). It gives evidence that the long-wave luminescence attributed to $\mathrm{T}^{2+} \mathrm{V}_{\mathrm{c}}-$ centers is slowly decaying.

Now we will focus on temperature behavior of the short-wave luminescence of $\mathrm{T}^{2+} \mathrm{V}_{\mathrm{c}}{ }^{-}$centers excited in $2.58 \mathrm{eV}$ absorption band. With temperature rise from $80 \mathrm{~K}$ to $200 \mathrm{~K}$ the luminescence band broadens and 


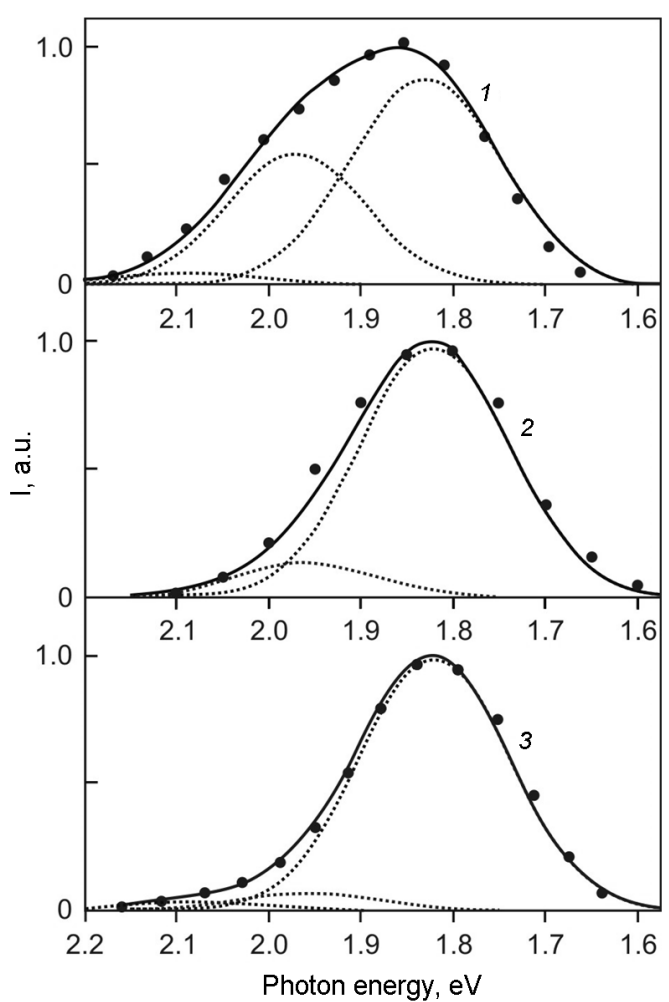

Fig. 5. Steady state luminescence spectra (1, 3) at $\lambda_{e x}=2.34 \mathrm{eV}$ and time-resolved luminescence spectrum at $\lambda_{e x}=2.29 \mathrm{eV}$ (2) were measured at $80 \mathrm{~K}$ for Csl:Tl containing comparable number of $\mathrm{TI}^{0} \mathrm{v}_{\mathrm{a}}{ }^{+}$and $\mathrm{Tl}^{2+} \mathrm{v}_{\mathrm{c}}{ }^{-}$centers $(1,2)$ and dominating number of $\mathrm{Tl}^{2+} \mathrm{v}_{\mathrm{c}}{ }^{-}$centers (3). Time-resolved luminescence spectrum (2) was registered with $1 \mu$ s delay after the exciting pulse depletion. Full circles - experimental values, dotted lines - fitting Gaussians, the solid line - the sum of Gaussians.

its maximum shifts from $2.08 \mathrm{eV}$ to $2.11 \mathrm{eV}$, respectively (Fig. 7). As one can see in Fig. 8 (curve 1), the intensity luminescence band diminishes within the temperature range of $80-200 \mathrm{~K}$ in accordance with the Mott's law. Table 3 lists the best fit parameter values for temperature dependence of the short-wave band intensity calculated by the equation (1). As temperature rises from $210 \mathrm{~K}$ to $295 \mathrm{~K}$ the luminescence band excited at $2.58 \mathrm{eV}$ decreases more essential than the one to be expected in the case Mott's quenching (Fig. 8, curves 1 , 2). The negative deviation from the Mott's law points to the existence of an additional quenching due to phonon-assisted depopulation of the level responsible for the short-wave luminescence of $\mathrm{T}^{2+} \mathrm{V}_{\mathrm{c}}{ }^{-}$centers. The equation (2) containing a correction for additional quenching [14] well fits the ex-

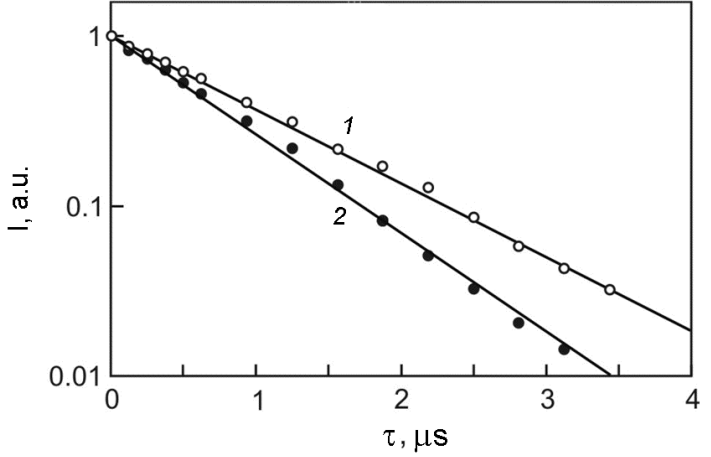

Fig. 6. Pulse decay of $1.82 \mathrm{eV}$ luminescence at excitation with $2.3 \mathrm{eV}$ laser emission pulse: 1) $T=80 \mathrm{~K}$, (empty circles - experimental values, solid line - the fitting curve; 2) $T=295 \mathrm{~K}$, full circles - experimental values; the solid line - the fitting curve $I(t)=I_{0} \exp (-t / 0.76)$.

Table 3. Best fitting set of parameters for temperature behavior of short-wave $\mathrm{Tl}^{2+} \mathrm{v}_{e}^{-}$ center luminescence

\begin{tabular}{|c|c|c|c|c||}
\hline$I_{0}$ & $\frac{p_{1}^{0}}{P_{L}}$ & $E_{1}(\mathrm{eV})$ & $\frac{p_{0}^{E}}{P_{L}}$ & $E_{2}(\mathrm{eV})$ \\
\hline 11.32 & 17.6 & 0.041 & 696280 & 0.27 \\
\hline
\end{tabular}

perimental data within whole temperature range from $80 \mathrm{~K}$ to $295 \mathrm{~K}$ :

$$
\begin{aligned}
& I_{2}(T)=\frac{I_{0}}{1+\frac{1}{P_{L}}\left(P_{1}+P_{E}\right)}= \\
& =\frac{I_{0}}{1+\frac{1}{P_{L}}\left(p_{0}^{1} e^{-\frac{E_{1}}{k T}}+p_{0}^{E} e^{-\frac{E_{E}}{k T}}\right)},
\end{aligned}
$$

where $I_{2}(T)$ - the temperature dependence of luminescence; $P_{E}$ and $E_{E}-$ the probability and activation energy for the process of additional quenching, respectively; $p_{0}^{E}$ - the pre-exponential factor inversely proportional to duration of the process. Table 3 lists the fit parameters for the equation (2).

At temperatures higher than $200 \mathrm{~K}$ which activate the additional quenching channel, the luminescence spectrum can not be fitted by one band. The sum of the shortand long-wave bands of $\mathrm{Tl}^{2+} \mathrm{V}_{\mathrm{c}}{ }^{-}$centers fits the luminescence spectrum excited in $2.58 \mathrm{eV}$ absorption band within a temperature range of 200-295 K (Fig. 7). The temperature increase causes short-wave shift of 

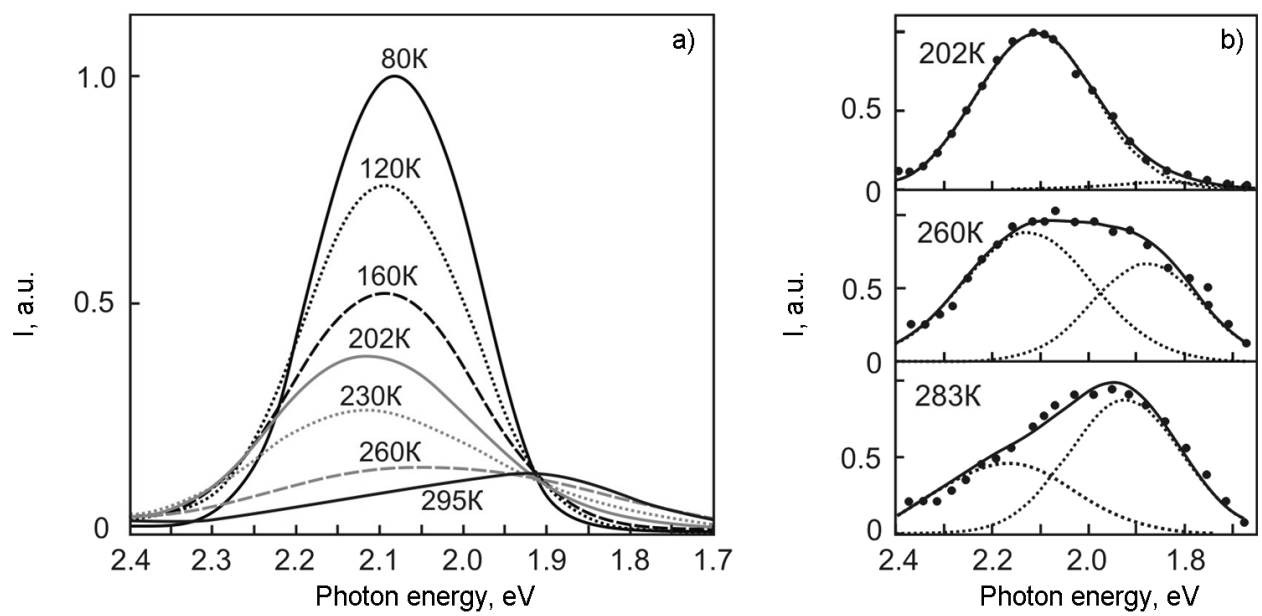

Fig. 7. a) Family of the luminescence spectra $\left(\lambda_{e x}=2.58 \mathrm{eV}\right)$ for the radiation-colored Csl:TI measured at different temperatures within a range of 80-295 K. b) The examples of fitting for the several luminescence spectra $\left(\lambda_{e x}=2.58 \mathrm{eV}\right)$ : full circles - experimental values; dotted lines fitting Gaussians, the solid line - the sum of Gaussians.

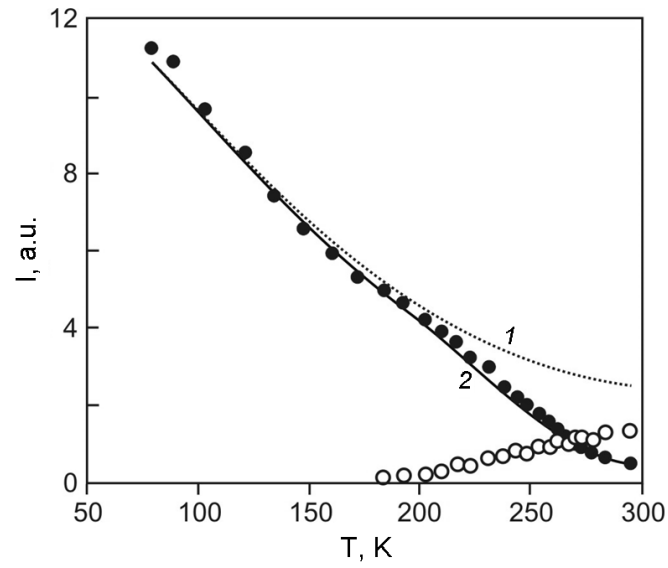

Fig. 8. Maximum intensity of the short and long-wave luminescence bands excited at $2.58 \mathrm{eV}$ versus temperature. Full and empty circles - experimental values for the short and long-wave band, respectively; the solid and dotted lines - the fitting curves calculated by the equation (1) and (2), respectively.

maxima and broadening of the both bands (Fig. 8). As one can see in Fig. 9, the share of the long-wave band to the total spectrum increases with the temperature to be in proportion to the quantum efficiency of quenching of short-wave band:

$$
\eta_{E}(T)=1-\frac{I_{2}(T)}{I_{1}(T)}=\frac{P_{E}}{P_{L}+P_{1}+P_{E}},
$$

where $I_{1}(T)$ - the short-wave band intensity taking into account of Mott's quenching, $I_{2}(T)$ - the short-wave band intensity taking into account of Mott's and additional quenching, $P_{L}-$ the probability of the intra-center luminescence, $P_{1}$ and $P_{E}-$ the probabilities of Mott's and additional quenching, respectively.

Temperature behaviour of $\mathrm{Tl}^{2+} \mathrm{V}_{\mathrm{c}}{ }^{-}$center luminescence at $2.58 \mathrm{eV}$ excitation can be explained by the phonon-assisted electron transition from the level related to the short-wave band to populate the level responsible for the long-wave luminescence. As seen from the data in Table 3, the activation energy of this process is $0.27 \mathrm{eV}$.

\subsection{Influence of radiation-induced color centers on energy transfer}

Scintillation detector based on Csl:Tl crystal operates within a temperature range of $210-330 \mathrm{~K}$, where luminescence of $\mathrm{T}^{0} \mathrm{v}_{\mathrm{a}}{ }^{+}$ color centers is virtually quenched. Absorbing $\mathrm{Tl}^{+}$center scintillations, they act as quenching centers responsible for light yield losses due to reabsorption. Unlike $\mathrm{T}^{0} \mathrm{v}_{\mathrm{a}}{ }^{+}$ centers, luminescence of $\mathrm{T}^{2+} \mathrm{V}_{\mathrm{c}}{ }^{-}$centers is not quenched in this temperature range. We found that non-radiative energy transfer from $\mathrm{Tl}^{+}$to $\mathrm{Tl}^{2+} \mathrm{v}_{\mathrm{c}}{ }^{-}$centers causes the change of the spectrum and shape of a scintillation pulse of $\gamma$-irradiated Csl:TI crystal [1]. Our understanding of the energy transfer mechanism was based on generally accepted views [15], that the luminescence bands peaking at 2.55 and $2.25 \mathrm{eV}$ in the spectrum of $\mathrm{Tl}^{+}$-scintillation are caused by $\mathrm{Tl}^{+}$perturbed excitons of "weak" and "strong" off-center configuration, respectively. But then studying Cs:Tl by time-resolved catho- 

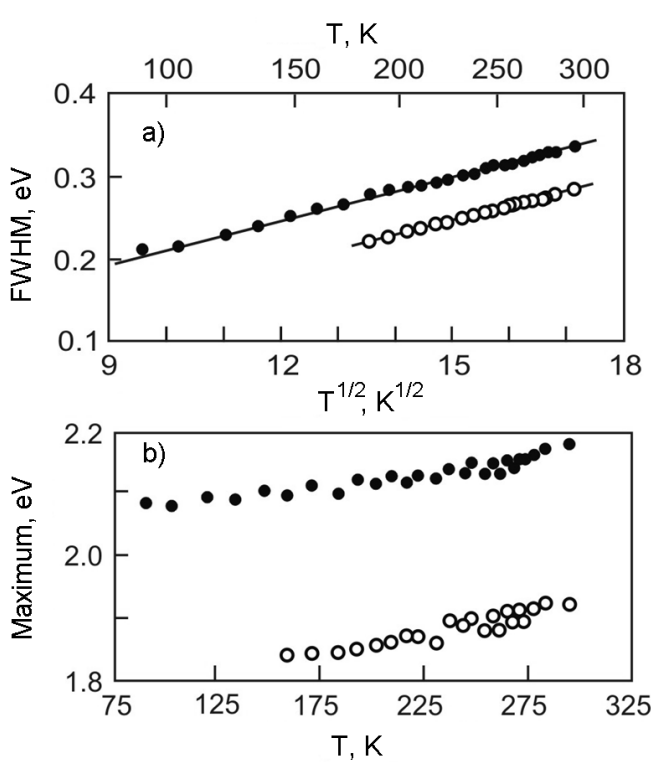

Fig. 9. FWHM (a) and maximum (b) versus temperature for two bands in luminescence spectrum of $\mathrm{TI}^{2+} \mathrm{v}_{\mathrm{c}}^{-}$centers excited at $E_{e x}=$ $2.58 \mathrm{eV}$.

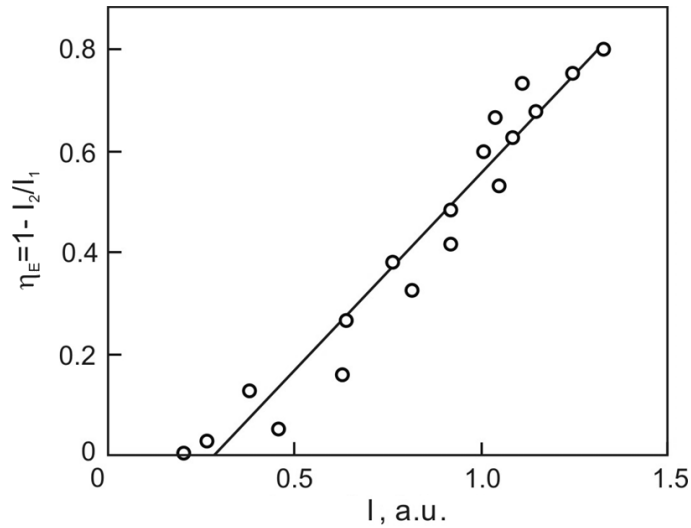

Fig. 10. Quantum efficiency of quenching of short-wavelength luminescence band versus the maximum intensity of long-wavelength luminescence band at a given temperature.

doluminescent spectroscopy in nano-, microand millisecond time scales we found the bands of $\mathrm{T}^{0}$ and $\mathrm{V}_{\mathrm{k}}$ color centers rather than the exciton bands in transient absorption spectra [16]. Williams corroborated these results [17] and experimentally proved [18] that $\mathrm{Tl}^{+}$ions in Csl lattice stimulate disintegration of excitons in the picosecond time scale. It means that 2.55 and $2.25 \mathrm{lu}-$ minescence bands have no exciton origin. Authors of [19] came to the same conclusion from a calculation on the structure of the STE in Csl, Csl:Tl, Csl:Na crystals. The results published in [16-19] strong prove that luminescence bands peaking at 2.55 and $2.25 \mathrm{eV}$ are caused by the tunnel electron

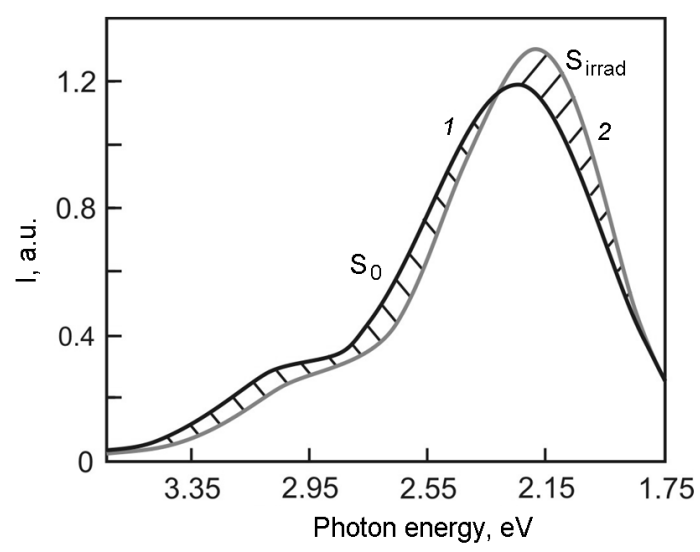

Fig. 11. Radio-luminescence spectra of CsI:TI crystal measured at $295 \mathrm{~K}$ before (1) and after the radiation-induced coloration (2).

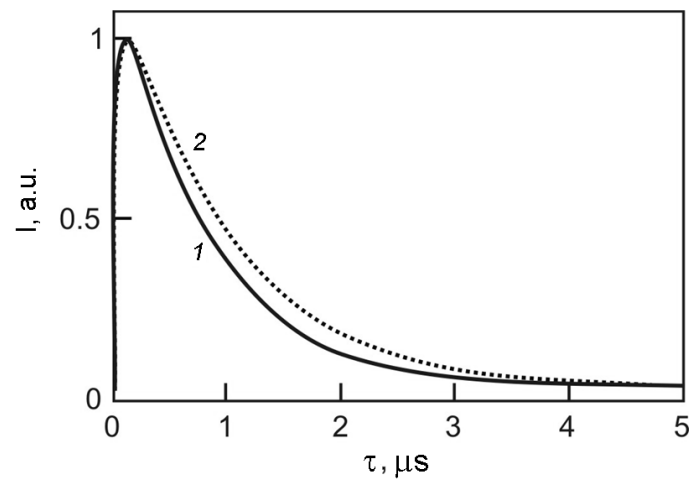

Fig. 12. Cathodoluminescence decay curves for radiation-colored Csl:TI crystal, which are registered at $2.25 \mathrm{eV}$ (1) and $1.82 \mathrm{eV}$ (2) under $295 \mathrm{~K}$.

transition from $\mathrm{T}^{0}$ on the ground level of $\mathrm{V}_{\mathrm{k}}$ center in close $\left[\mathrm{TI}_{0} \mathrm{~V}_{\mathrm{k}}\right]$ pairs having two different geometrical configurations.

Regarding the energy transfer mechanism, it should be note that besides $\mathrm{Tl}^{+}$bands peaking at 2.55 and $2.25 \mathrm{eV}$, the scintillation spectrum of the radiation-damaged Csl:Tl crystal measured at $80 \mathrm{~K}$ also contains both bands of $\mathrm{T}^{2+} \mathrm{V}_{\mathrm{c}}{ }^{-}$centers and the sum of three exponents with time constants $\tau_{1}=1.0 \mu \mathrm{s}, \tau_{2}=3.0 \mu \mathrm{s}$ and $\tau_{3}=10 \mu \mathrm{s}$ fits the scintillation pulse decay kinetics [1]. The double-exponential function with $\tau_{2}=3.0 \mu \mathrm{s}$ and $\tau_{3}=10.0 \mu \mathrm{s}$ fits the luminescence decay kinetics of $\mathrm{Tl}^{+}$centers, whereas mono-exponential function with $\tau_{1}=1 \mu \mathrm{s}$ fits to the luminescence decay kinetics of luminescence attributed to $\mathrm{Tl}^{2+} \mathrm{V}_{\mathrm{c}}{ }^{-}$ centers. In term of the tunnel recombination luminescence model, the excited state of $\mathrm{Tl}^{+}$-center is considered to be $\left[\mathrm{Tl}_{0} \mathrm{~V}_{\mathrm{k}}\right]$ donor-acceptor pair, therefore the resonance energy transfer from the excited $\mathrm{Tl}^{+}$center 
to $\mathrm{Tl}^{2+} \mathrm{V}_{\mathrm{c}}{ }^{-}$center could be realized by electron transition from the $6^{2} \mathrm{P}_{1 / 2}$ level of $\mathrm{Tl}^{0}$ center to an excited level of $\mathrm{T}^{2+}$ center perturbed by a cation vacancy $\mathrm{v}_{\mathrm{c}}{ }^{-}$. The overlap of wave functions for $\mathrm{Tl}^{0}$ donor and $\mathrm{Tl}^{2+} \mathrm{V}_{\mathrm{C}}{ }^{-}$ acceptor is the resonance condition, from which it follows that these centers have energy levels to be found at the same distance from valence band top. The overlap is provided by large number of close $\left\{\mathrm{T}^{0} \mathrm{~V}_{\mathrm{k}}\right\}$ pairs forming in the scintillation process and some of them is found near $\mathrm{Tl}^{2+} \mathrm{V}_{\mathrm{c}}{ }^{-}$centers arising due to radiation damage. The decay component with $\tau_{1}$ time constant is due to capture of conduction electrons by $\mathrm{T}^{2+} \mathrm{V}_{\mathrm{c}}{ }^{-}$ centers. The process involving $\mathrm{Tl}^{2+} \mathrm{V}_{\mathrm{c}}{ }^{-}$color centers causes the change of the scintillation spectrum. Comparing radioluminescence spectra measured before and after radiation damage of Csl:Tl crystal, one can see that $\mathrm{Tl}^{2+} \mathrm{V}_{\mathrm{C}}{ }^{-}$centers cause decrease of the light sum emitted in the short-wave range $\left(S_{0}\right)$ to be completely compensated by the increase of the light sum emitted in long-wave region $\left(S_{\text {irrad }}\right)$ (Fig. 11). $\mathrm{Tl}^{2+} \mathrm{V}_{\mathrm{c}}{ }^{-}$centers are also responsible for the change of the scintillation decay kinetics, which becomes selective. This illustrates Fig. 12, where one can see, that a cathodoluminescence pulse registered in short-wavelength spectral range decays faster than in long-wavelength range. The increase of the scintillation pulse duration is explained by the resonance energy transfer from $\mathrm{Tl}^{+}$to $\mathrm{Tl}^{2+} \mathrm{V}_{\mathrm{C}}{ }^{-}$center with following phonon-assisted intra-center transition, which gives rise the long-wave luminescence decaying with time constant equal $0.76 \mu \mathrm{s}$ at room temperature (see Fig. 6).

\section{Conclusions}

Electronic $\mathrm{T}^{0} \mathrm{~V}_{\mathrm{a}}{ }^{+}$and hole $\mathrm{T}^{2+} \mathrm{V}_{\mathrm{c}}{ }^{-}$color centers arising due to radiation damage do not reduce conversion efficiency of CsI:T| crystal, but participate in scintillation process to get energy from $\mathrm{Tl}^{+}$centers by resonance. Degradation of the light yield of the radiation-damaged Csl:Tl crystal is due to the radiative energy transfer from $\mathrm{Tl}^{+}$to $\mathrm{T}^{0} \mathrm{~V}_{\mathrm{a}}{ }^{+}$centers, whose emission is quenching at operating temperature $(210-330 \mathrm{~K})$ of CsI:Tl scintillator. Non-raditive energy transfer from $\mathrm{Tl}^{+}$to $\mathrm{T}^{2+} \mathrm{V}_{\mathrm{c}}{ }^{-}$centers results in long-wave spectral shift and the duration increase of the scintillation response of Csl:Tl.

\section{References}

1. V.Yakovlev, L.Trefilova, A.Meleshko, J.Luminescence, 128, 1447 (2008).

2. L.N.Shpilinskaya, D.I.Zosim, L.V.Kovaleva et al., in: Proc. 5th Int. Conf. on Inorganic Scintillators and their Applications, Moscow, Russia (2000), p.538.

3. R.Zhu, in: Proc. 5th Int. Conf. on Inorganic Scintillators and their Applications", Moscow, Russia (2000), p.73.

4. D.M.Beylin, A.I.Korchagin, A.S.Kuzmin et al., Nucl.Instr. Meth.Phys. Res. A, 541, 501 (2005).

5. S.Longo, J.M.Roney, J. Instrumentation, 11, P08017 (2016).

6. M.E.Globus, B.V.Grinyov, M.A.Ratner, Proc. SPIE, 3446, Hard X-Ray and Gamma-Ray Detector Physics and Applications, 242 (July 1, 1998) doi:10.1117/12.312897.

7. M.Ratner, B.Grinyov, A.Ratner, Rad.Meas., 38, 627 (2004).

8. I.A.Beresin, V.M.Gorbachev, V.V.Kuzjanov et al., Atom. Energy, 35, 1055 (1973).

9. M.M.Hamada, F.E.Costa, S.Shimizu et al., Nucl. Instr. Meth. Phys. Res. A, 486, 330 (2002).

10. L.Trefilova, T.Charkina, A.Kudin et al., J. Luminescence, 102-103, 543 (2003).

11. L.Trefilova, B.Grinyov, V.Alekseev et al., IEEE Trans. Nucl. Sci., 55, 1263 (2008).

12. G.A.Babich, A.B.Blank, E.P.Kisil et al., Functional Materials, 8, 369 (2001).

13. V.Alekseev, I.Golub, M.Grinberg et al., Optical Materials, 30, 711 (2008).

14. A.F.Zatsepin, D.Yu.Biryukov, V.S.Kortov et al., Phys. Solid State, 44, 1671 (2002).

15. V.Nagirnyi, A.Stolovich, S.Zazubovich et al., J.Phys.:Condens. Matter, 7, 3637 (1995).

16. V.Yakovlev, L.Trefilova, A.Meleshko, J.Luminescence, 129, 790 (2009).

17. R.T.Williams, K.B.Ucer, J.Q.Grim et al., IEEE Trans. Nucl.Sci., 57, 1187 (2010).

18. K.B.Ucer, G.Bizarri, A.Burger et al., Phys. Rev. B, 89, 165112 (2014).

19. Chun-Rong $\mathrm{Fu}$, Ling-Fu Chen, K.S.Song, $J$. Phys.:Condens. Matter, 11, 5517 (1999). 